\title{
Geochemical and Petrographic Characterization of Bricks and Mortars of the Parish Church SANTA Maria in Padovetere (Comacchio, Ferrara, Italy)
}

\author{
Elena Marrocchino ${ }^{1, *}\left(\mathbb{D}\right.$, Chiara Telloli $^{2}\left(\mathbb{D}\right.$, Mario Cesarano $^{3}$ and Manlio Montuori ${ }^{4}(\mathbb{C}$ \\ 1 Department of Physics and Earth Sciences, University of Ferrara, via Saragat 1, 44121 Ferrara, Italy \\ 2 ENEA, Italian National Agency for New Technologies, Energy and Sustainable Economic Development \\ Fusion and Technology for Nuclear Safety and Security Department Nuclear Safety, Security and \\ Sustainability Division, via Martiri di Monte Sole 4, 40129 Bologna, Italy; chiara.telloli@enea.it \\ 3 Ministry of Culture, Superintendence Archaeology, Fine Arts and Landscape of Naples Metropolitan Area, \\ Piazza Museo Nazionale, 19, 80135 Napoli, Italy; mario.cesarano@beniculturali.it \\ 4 Department of Architecture, University of Ferrara, via della Ghiara 36, 44121 Ferrara, Italy; \\ manlio.montuori@unife.it \\ * Correspondence: mrrlne@unife.it; Tel.: +39-3393-807477
}

check for updates

Citation: Marrocchino, E.; Telloli, C.; Cesarano, M.; Montuori, M. Geochemical and Petrographic Characterization of Bricks and Mortars of the Parish Church SANTA Maria in Padovetere (Comacchio, Ferrara, Italy). Minerals 2021, 11, 530. https://doi.org/10.3390/ $\min 11050530$

Academic Editor: Elisabetta Boaretto

Received: 14 April 2021

Accepted: 15 May 2021

Published: 18 May 2021

Publisher's Note: MDPI stays neutral with regard to jurisdictional claims in published maps and institutional affiliations.

Copyright: (c) 2021 by the authors. Licensee MDPI, Basel, Switzerland. This article is an open access article distributed under the terms and conditions of the Creative Commons Attribution (CC BY) license (https:// creativecommons.org/licenses/by/ $4.0 /)$.
Abstract: From the 1950s and 1960s of the last century, a parish church dating back to the 6th century AD was identified during reclamation works of Valle Pega. The archaeological investigation allowed the recovery of the parish and the attached baptistery, as well as some tombs closely connected to the church. Following the excavation, it was possible to collect some samples of bricks and mortars in order to identify the different compositions of the materials used for the construction of the parish. All the samples were analyzed through optical microscopy, X-ray powder diffractometric analysis and observation through scanning electron microscope. Thanks to the investigations carried out on the samples, it was possible to hypothesize the different construction phases and the different materials used and to identify the firing temperatures at which the bricks were built.

Keywords: archeological bricks; petrographic analysis; morphological description; Ferrara

\section{Introduction}

The territory of the current Municipality of Comacchio, in the province of Ferrara (north of Italy), is identified with a part of the River Po's ancient delta, which has undergone many changes over the centuries [1-3].

There are numerous archeological finds reported over the duration of the settlement of populations from the late ancient and medieval ages, which interfered with the natural landscape modifying it with anthropic constructions [4-6]. In particular, thanks to the discoveries by Greek and Roman geographers, the city of Spina (actually in the Municipality of Comacchio) is known to reach an exceptional level of economic life [7-9].

Archeological research began in 1956 in the area around Santa Maria in Padovetere, following the unexpected discovery of the remains of the church of Pieve di Santa Maria in Padovetere [10,11], after the excavation of a drainage canal for land reclamation between Valle Pega and Valle del Mezzano, in the municipality of Comacchio. The excavations showed the single apse hall plan of the church, the polygonal baptistery, and a series of rooms whose presence in the area was not clearly interpretable. Nevertheless, the few remains of the architectural and decorative site were not enough to provide a picture of the structural and decorative condition of the church.

The excavation works were resumed between 2014 and 2015 [12]. In the center of the valley, in fact, towards the 1950s, a church dedicated to Santa Maria was found, near the Po di Spina branch, called Padovetere or Padus Vetus. It is the oldest ecclesiastical complex in 
the Comacchio area. The foundation of the building dates to the time of Bishop Aureliano (519-521 AD) [13,14].

This work aims to characterize bricks and mortars used in the construction of the archeological site of Santa Maria in Padovetere and to correlate how these materials could be traced back to different construction phases of the site.

The close relationship between bricks firing and natural processes leading to the petrogenesis of thermos-metamorphic phases has already been underlined [15-17]. Therefore, bricks can be considered as artificial rocks produced by baking (industrial metamorphism) and the analysis of these could be analogue to the study of metamorphic rocks. As a matter of that, in bricks the minerals derived from firing commonly grow both by replacing mineral phases already present in clay and along the edges of the grains of phases with different chemism [18]. These reactions allow understanding of some of the dynamic aspects of the process, from the moment in which some relict grains coexist with different firing phases; the growth of a mineral phase is related to both the firing temperatures and the composition of it. Consequently, analyzing samples of brick by X-ray powder diffractometric analysis (XRPD), it allowed to recognize the mineralogical phases of the observed sample and make hypotheses on the production and formation of bricks and mortars $[19,20]$.

Chemical and petrographic analyses were also conducted on all samples through macroscopically and microscopically characterization and observation by Scanning Electron Microscope (SEM-EDS) [21].

In addition, soils collected in the Valle del Mezzano allow characterization of the samples based on the origin of the materials (bricks and mortars) used in the construction of the parish, in order to better understand the environmental context [22] through X-ray fluorescence (XRF) analysis.

\section{Materials and Methods}

\subsection{Sampling}

In the Valle Pega area, located in the municipality of Comacchio in the province of Ferrara (Emilia Romagna region, north east of Italy), there are the remains of the ancient early Christian parish church of Santa Maria in Padovetere, an ecclesial system dating back to 6th century AD. The archeological site is surrounded by a large and partially inhabited rural area, mainly used for agriculture.

Archeological excavations made it possible to obtain the following information: the church was characterized by a single rectangular room and a semi-circular apse, both internal and external, connected to the perimeters by means of two straight walls (Figure 1). The foundation of a connecting wall closed the apsidal part inside with probable static function. The maximum length of the building was $15.30 \mathrm{~m}$, while the only room externally measured $11.65 \mathrm{~m}$ and the maximum width was $8.30 \mathrm{~m}$. All the walls and foundations, made of brick, had a constant thickness of $1 / 1.05 \mathrm{~m}$, except for the facade wall which was only $65 \mathrm{~cm}$. The whole structure was affected in 1956 by the excavation of the canal for hydraulic reclamation, as a result of which the south-western corner of the room and the adjacent room was missing. No trace of the original floor had been preserved [13]. The church had an east-west orientation. To the north of it, there was the baptistery with a polygonal plan (11 sides) on the outside and circular inside, with an entrance from the east/south-east. The entrance was made up of a conglomerate slab with two red ammonite slabs on the right and left sides, respectively. These slabs were clearly of "redevelopment", that is put in place during the interventions of restoration between the 1950s and 1970s. The internal tank, whose depth was to reach about $50 / 60 \mathrm{~cm}$, was located in the center of the building and had a circular shape on a hexagonal base. Its presence suggested that in the surrounding area there was the presence of a settlement or a village, which considered this building and the adjacent church a place of worship. 

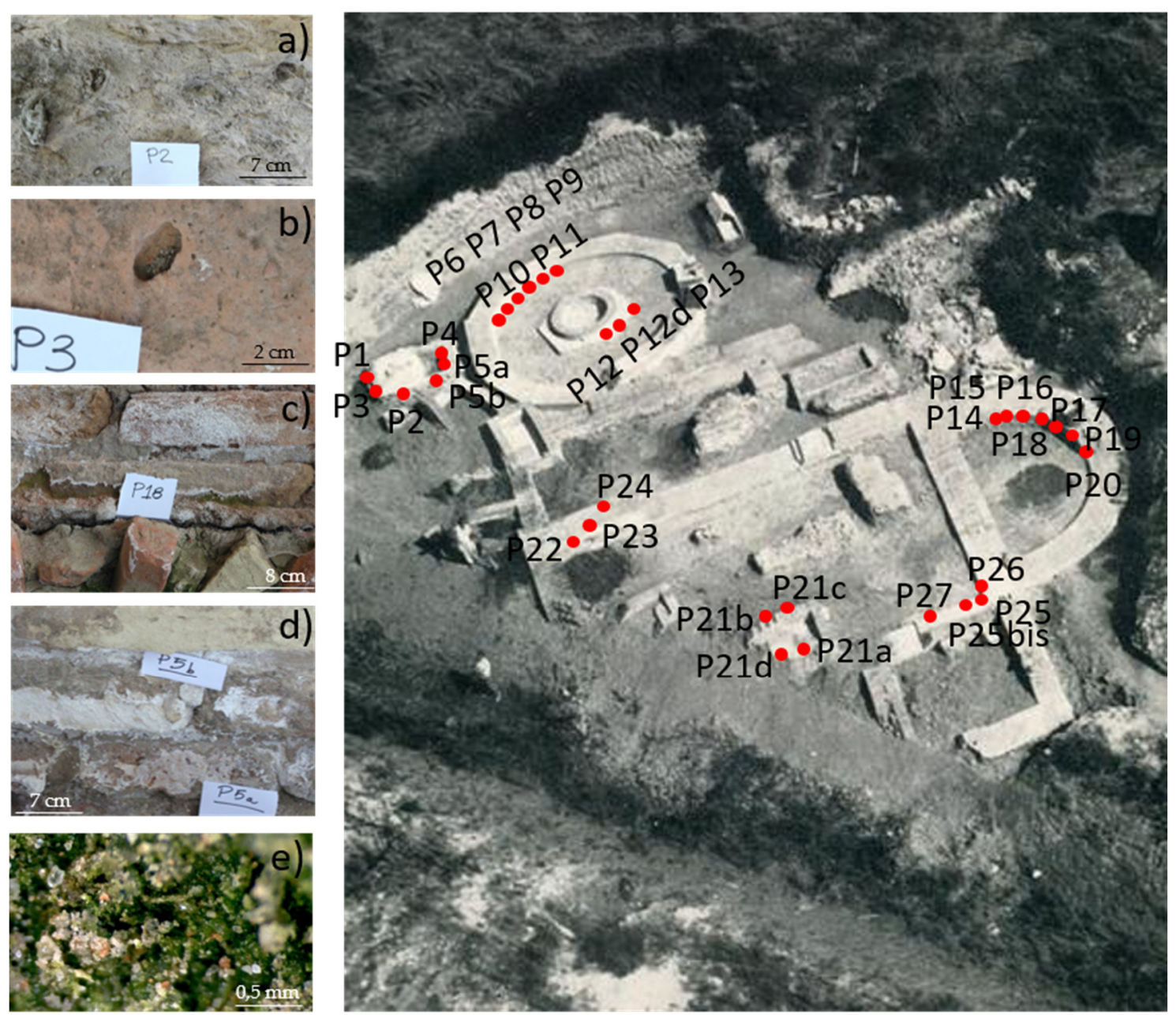

Figure 1. Map of the sampling site of Santa Maria in Padovetere; colored in red the samples collected of bricks, mortars and salt crusts. From P14 to P20 it was a stratigraphic type, therefore taken vertically, starting from the base of the foundations. Example of samples collected: (a) albasi brick; (b) red brick; (c) mortar; (d) salt crust; (e) example of biological degradation due to the presence of algal biofilm.

Different types of samples were collected including bricks and mortars constituting the archeological site plus four samples of salt crusts (samples P4, P5a, P5b and P19). All the samples were collected in the basal part of the site (Figure 1), since it was subject to "redevelopment" works that took place between the 1950s and the 1970s, during which new production bricks were placed outside above the ancient ones. In this way, it should be possible to recognize the various construction phases, also considering the possible use of reuse materials. From P14 to P20 samples, they represented a stratigraphic sampling taken vertically, starting from the base of the foundations.

Most of the samples collected showed evident signs of degradation, which in the case of the bricks and mortars led to a worsening of the chemical-physical and structural characteristics. Some samples showed the development of biological agents: for example, bacteria, fungi, algae, lichens, or plants (as shown, for example, in Figure 1e), probably caused by the excessive presence of water. In many other samples there was the formation of crusts (as shown in Figure 1d), erosion of surfaces or presence of fractures (as shown in the albasi brick of Figure 1a and in the red brick of Figure 1b). These bricks had been exposed to aerial and/or burial environments which could have favored the degradation of the materials. The location of the bricks and the environments to which they had been exposed, the action of natural or polluted filtration water, the action of microorganisms, the 
development of the roots and aerial structures of weeds and the reigning environmental conditions, all contributed towards the state of conservation of the bricks [23].

All the samples were collected and transported to the laboratories of the Department of Physics and Earth Sciences, University of Ferrara, in order to prevent contamination by modern bacteria or biological agent related to atmospheric conditions or by the intervention of operators, especially in the samples characterized by biological degradation (as shown, for example, in Figure 1e).

To better characterize the samples of bricks and mortars, soil samples were collected in the Valle del Mezzano, near to Valle Pega [24]. The chosen sites were located in the paleochannel of the Mezzano (Figure 2), an area which was dried up with the reclamation of the 1960s, and which corresponds to marshy areas in which silty sediments prevail. Seven samples of soil were collected by drilling at a depth of $50 \mathrm{~cm}$ extracting a volume of soil equal to $250 \mathrm{~cm}^{3}$. The strictly superficial part of the soil was removed, in order to obtain the least possible alteration of the samples. A briefly description of the difference of the soil samples is shown in Table 1 and explained below. In detail, samples 1, 3, 4, 5 and 7 (CSP1) represented a very deep soil; peaty and extremely saline, scarcely or moderately calcareous and weakly alkaline in the upper part, from extremely to weakly acidic in the lower part. The substrate consisted of calcareous sediments due to internal flows of acidic waters, medium texture and with poorly decomposed organic materials. Sample 2 (BUR1/MOT1) was characterized by very deep, non-calcareous or very poorly calcareous soil, with a course to medium texture and weakly acidic or weakly alkaline, very rich in organic materials in the upper part, with a coarse texture and strongly acidic in the lower one. Sample 6 (AGO1), on the other side, consisted of very deep and extremely saline soil; from non-calcareous to moderately calcareous, moderately alkaline and organic in the upper part; not limestone, strongly or moderately acid, with loamy clay free or loamy loam texture in the lower one. Coarse-textured sediments represented the substrate.

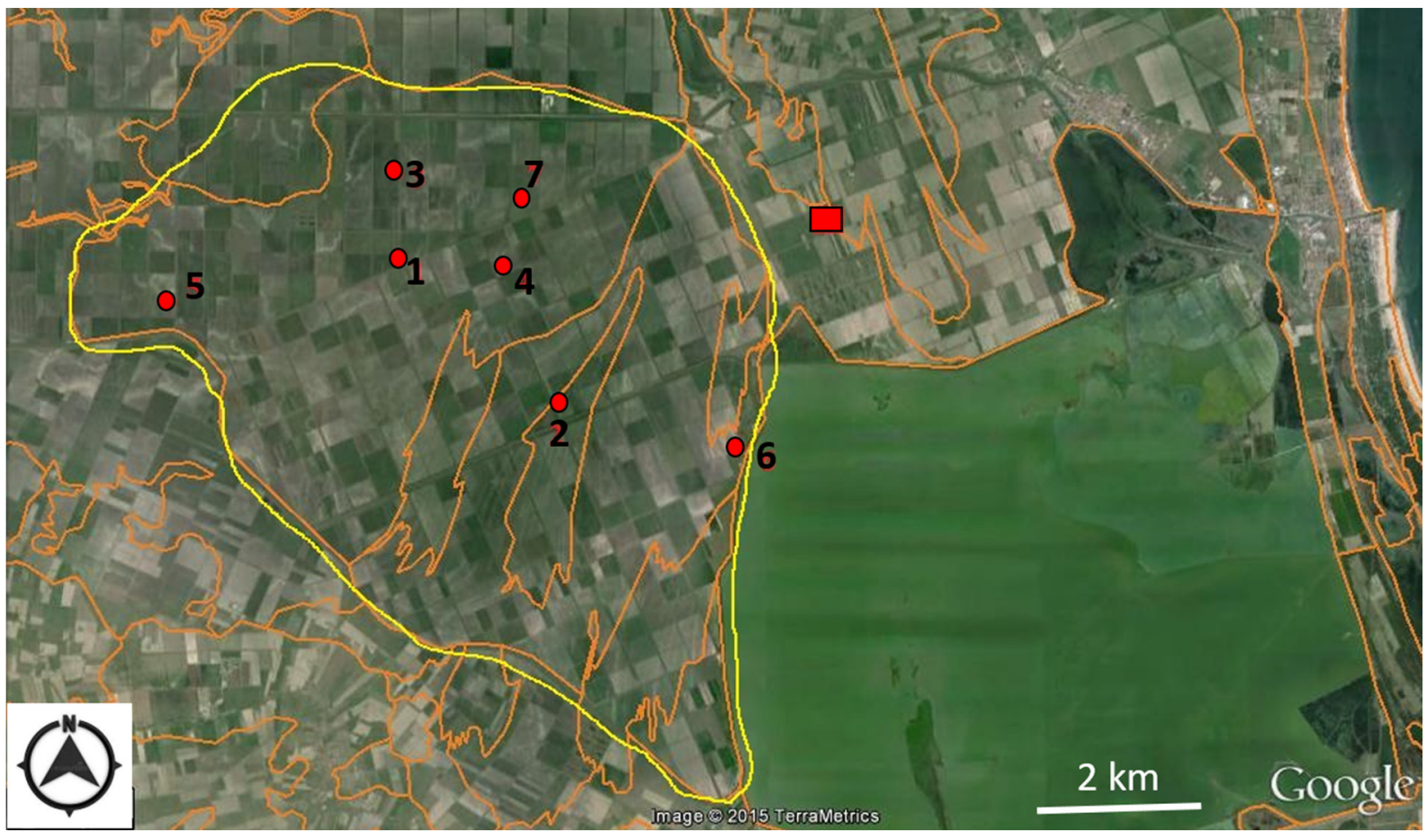

Figure 2. Map of the soil sampling site in the Valle del Mezzano. Colored in red the soil samples collected. Border in yellow the area that represent the Valle del Mezzano. The red square represents the archeological site of Santa Maria in Padovetere in Valle Pega. 
Table 1. Briefly description of the main differences between the different kind of soil samples collected in Valle del Mezzano and Valle Pega.

\begin{tabular}{|c|c|c|}
\hline Sample Number & & Type of Soil \\
\hline $1,3,4,5,7$ & CSP1 & $\begin{array}{c}\text { Saline soil, scarcely or moderately calcareous, weakly } \\
\text { alkaline in the upper part and weakly acidic in the } \\
\text { lower part }\end{array}$ \\
\hline 2 & BUR1/MOT1 & $\begin{array}{c}\text { Non-calcareous or very poorly calcareous soil rich in } \\
\text { organic materials }\end{array}$ \\
\hline 6 & AGO1 & $\begin{array}{c}\text { Saline soil, from non-calcareous to moderately } \\
\text { calcareous }\end{array}$ \\
\hline
\end{tabular}

\subsection{Chemical and Mineralogical Characterization}

Microscopic observation of bricks, mortars and salt crusts sampled was conducted using two different optical microscopes. The optical stereomicroscope Optika SZ6745TR (Ponteranica, Bergamo, Italy) and the optical stereomicroscope Optika 600 (Ponteranica, Bergamo, Italy) together equipped with MOTICAM 2500 5.0M pixel webcam were used for reflected light observation. The Motic Images Plus 2.0 ML software (Micromed, Russia) was used to analyze the observation obtained. The difference between the two different stereomicroscopes was the magnification type: Optika SZ6745TR has magnifications ranging from $0.67 \times$ to $4.5 \times$, instead of Optika 600 has magnifications ranging from $5 \times$ to $50 \times$ [25].

Moreover, mineralogical determinations of the same samples, previously grinded using water and then dried, were carried out through X-ray powder diffractometric analysis (XRPD) using a Philips PW1830/00 diffractometer, with a graphite filtered and a $\mathrm{Cu} \mathrm{K} \alpha$ radiation $(1.542 \AA)$ in a two $\theta$ angular range $5-75^{\circ}$, with a $5 \mathrm{~s} /$ step $\left(0.02^{\circ} 2 \theta\right)$ [26]. The data obtained were processed with the XPowder12 software (Martillo Sigmar Software, Spain) to determine the size and the strain Fourier coefficients necessary to perform a Warren-Averbach line profile analysis [27].

In addition, four samples of both red and albasi bricks (P16, P20, P21c, P27) plus a sample of salt crusts (P5b) and a sample of base clay (P14) were selected for morphological observations by the scanning electron microscope (SEM). The morphological and chemical characterization was carried by a scanning electron microscope (SEM) Zeiss EVO MA15-HR (Carl Zeiss AG, Oberkochen, Germany) equipped with an Energy Dispersive X-ray Spectrometer (EDS) INCA 300 (Oxford Instruments, Abingdon, UK) for X-ray microanalysis [28]. The SEM-EDS high magnification images of the sample surfaces were performed using the OXFORD INCA EDS system (Oxford Instruments, Abingdon, UK) which consists of an INCA $x$-sight EDS detector and an INCA x-stream pulse processor. For each selected sample, the thin section that was not metalized was firmed on a SEM stub utilizing double-sided conductive adhesive tape.

On the other side, the soil samples were firstly dried in an oven at $105^{\circ} \mathrm{C}$, then ground until a powder with a particle size less than $2 \mu \mathrm{m}$ was obtained. The powders obtained were also dried in an oven at $500-550{ }^{\circ} \mathrm{C}$ for $21 \mathrm{~h}$ to remove the organic compounds. The powders were prepared by pressing the tablets on boric acid support for XRF analysis. The chemical characterization of the collected samples was determined by X-Ray Fluorescence (XRF) analysis, carried out at the Department of Physics and Earth Sciences, University of Ferrara, with a wavelength dispersion spectrometer ARL Advant-XP (Thermo Fisher Scientific, Waltham, MA, USA) [29]. This technique allowed the determination of the major elements, expressed as a percentage by oxide weight $\left(\mathrm{SiO}_{2}, \mathrm{TiO}_{2}, \mathrm{Al}_{2} \mathrm{O}_{3}, \mathrm{Fe}_{2} \mathrm{O}_{3}\right.$, $\mathrm{MnO}, \mathrm{MgO}, \mathrm{CaO}, \mathrm{Na}_{2} \mathrm{O}, \mathrm{K}_{2} \mathrm{O}, \mathrm{P}_{2} \mathrm{O}_{5}$ ), and of the following trace elements reported in ppm (parts per million): $\mathrm{Ba}, \mathrm{Ce}, \mathrm{Co}, \mathrm{Cr}, \mathrm{La}, \mathrm{Nb}, \mathrm{Ni}, \mathrm{Pb}, \mathrm{Rb}, \mathrm{Sr}, \mathrm{Th}, \mathrm{V}, \mathrm{Y}, \mathrm{Zn}, \mathrm{Zr}, \mathrm{Cu}, \mathrm{Ga}$, $\mathrm{Nd}, \mathrm{S}, \mathrm{Sc}$. The detection limit ( $0.01 \%$ for major oxides) was estimated to be close to ppm for most trace elements, except for $S$ for which $50 \mathrm{ppm}$ was considered. The accuracy of the instrument, estimated on the basis of the results obtained on international standards of geological samples, and the precision, expressed as standard deviation of replicated 
analyses, were between $2 \%$ and $5 \%$ for the major elements and between $5 \%$ and $10 \%$ for trace elements [30]. The processing of the acquired intensities and the correction of the matrix effect was performed according to the model proposed by Lachance and Trail [31].

\section{Results}

\subsection{Macroscopic Characterization}

Two types of bricks were analyzed: albasi brick and red brick [32,33].

The albasi brick was heterogeneous but porous (Figure 1a). At first observation, the clay appeared to be well screened: the evident presence of inclusions or size differences of the aggregate clasts was not exactly defined. The pores were also clearly visible (samples P2, P7, P15, P20, P22). The sample P21c, on the other hand, shows a scaly appearance and seems to be prepared with not well screened raw clays. It appeared with a color zonography that led to hypothesize the employment of different raw clay. The matrix, in fact, came out to be more crystalline with different textures within the sample itself that exhibit some areas more vitrified than others.

On the other hand, the red brick (Figure 1b) showed flaking and alterations probably due to the exposure to atmospheric agents or to underground brackish water moisture [33], which could have favored salts deposition on and in the materials and induced the material decay (samples P3, P10, P16, P21b, P21d, P27). The pores were clearly visible, and the derived clay was also well screened. Some samples presented saline crusts (samples P9, P11, P12, P17, P24), while others displayed the presence of biological aggression extended to the whole surface of algal biofilm and a strong musty smell (samples P25, P25bis, P26).

The mortar samples appeared incohesive and tended to crumble (Figure 1c). They presented a powdery appearance (samples P1, P13, P18, P23). Some samples shown the presence of saline crusts (sample P6) and others of biological aggression (sample P8). Sample P21a was a cohesive mortar with medium-sized pebbles of about $2 \mathrm{~cm}$ in diameter, with a rounded shape; this was probably the laying surface of what should have been the pulpit. While the sample P14 was probably a base clay of the foundation.

Samples P4, P5a, P5b and P19 were saline crusts (Figure 1d). They presented a massive and translucent appearance and extended humidity [34,35].

\subsection{Optical Microscopic Characterization}

All samples of bricks, mortars and salt crusts were observed under optical microscope. Figure 3 shown photo imaging of each sample obtained at a magnification of $0.67 \times$.

The analyses of the albasi brick confirmed the macroscopic observation related to the presence of pores and a heterogeneous matrix (Figure 3a,b).

Additionally, for the red brick, visible pores were observed but with a matrix more compact respect to albasi brick. Some samples presented flaking and/or alterations or different color (grey), as shown in Figure 3c, probably due to different firing temperature and so different degree of crystallization or due to deformation and/or degradation (this will be explained better through SEM-EDS analyses).

Figure 3d,e represented two different type of mortar samples collected in the sampling site. Sample P8 appeared incohesive and tended to crumble with different grain sizes and different kinds of minerals inside a thin matrix. On the other hand, sample P14 was characterized by a cohesive matrix that could confirm the hypothesis of a base clay of the foundation.

Optical microscopy of the samples presented in Figure $3 f$ show that the surface zone is enriched in saline crust [36].

The samples collected in the archeological site of Santa Maria in Padovetere shown the presence of microscopic faunal settlements (given by spider lairs and insects) and of colonization of microorganisms, such as alga.

The images in Figure 4 are photographs of some selected samples with insects and insects' activities. The photos were obtained by a 5.0 Mp OPTIKA SZ 6745TR optical microscope. 

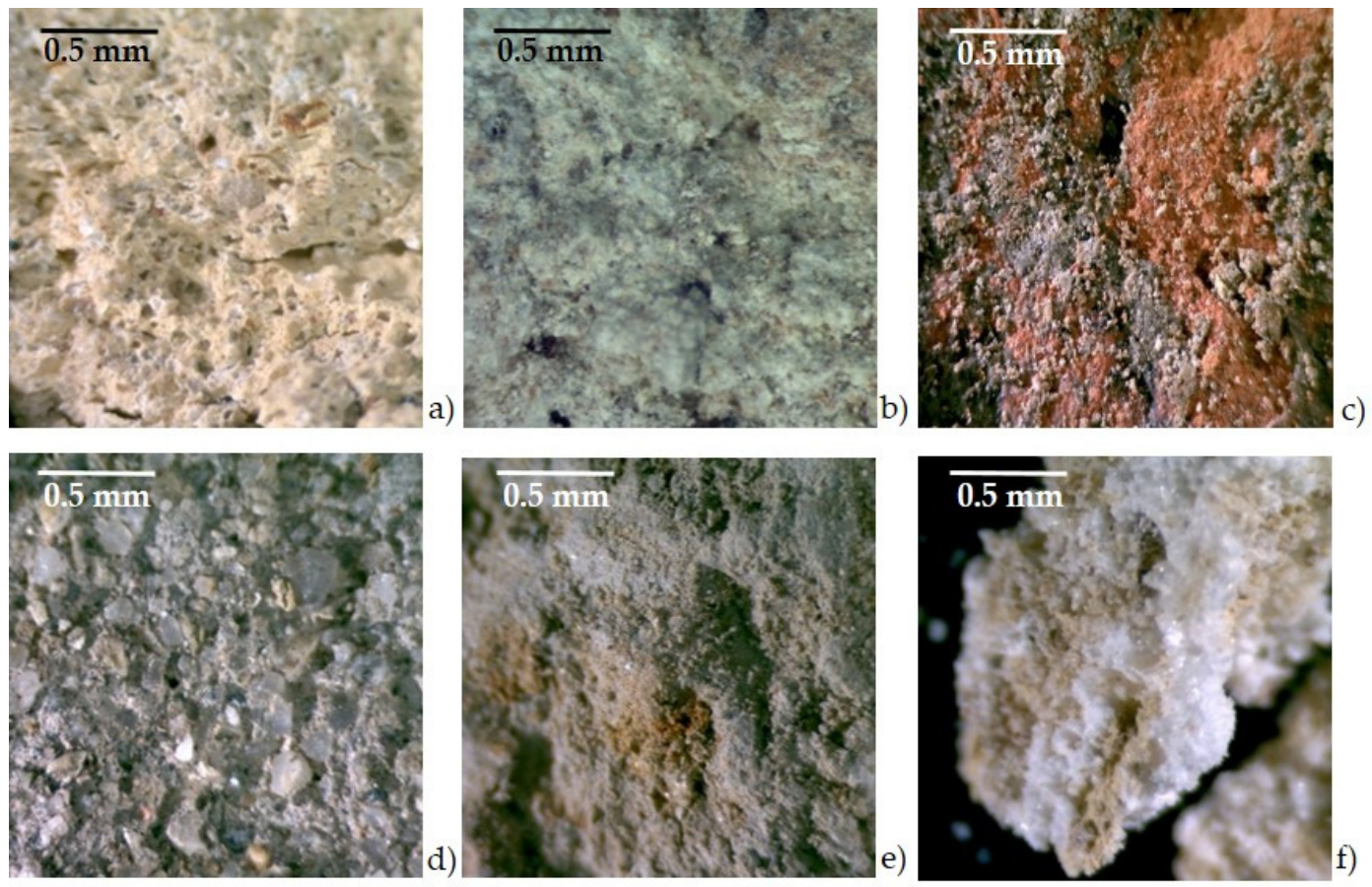

Figure 3. Optical microscopic images obtained at a magnification of $0.67 \times$ : (a) albasi brick, sample P20; (b) albasi brick, sample P21c; (c) red brick, sample P27; (d) mortar, sample P8; (e) mortar, sample P14; (f) salt crust, sample P5b.
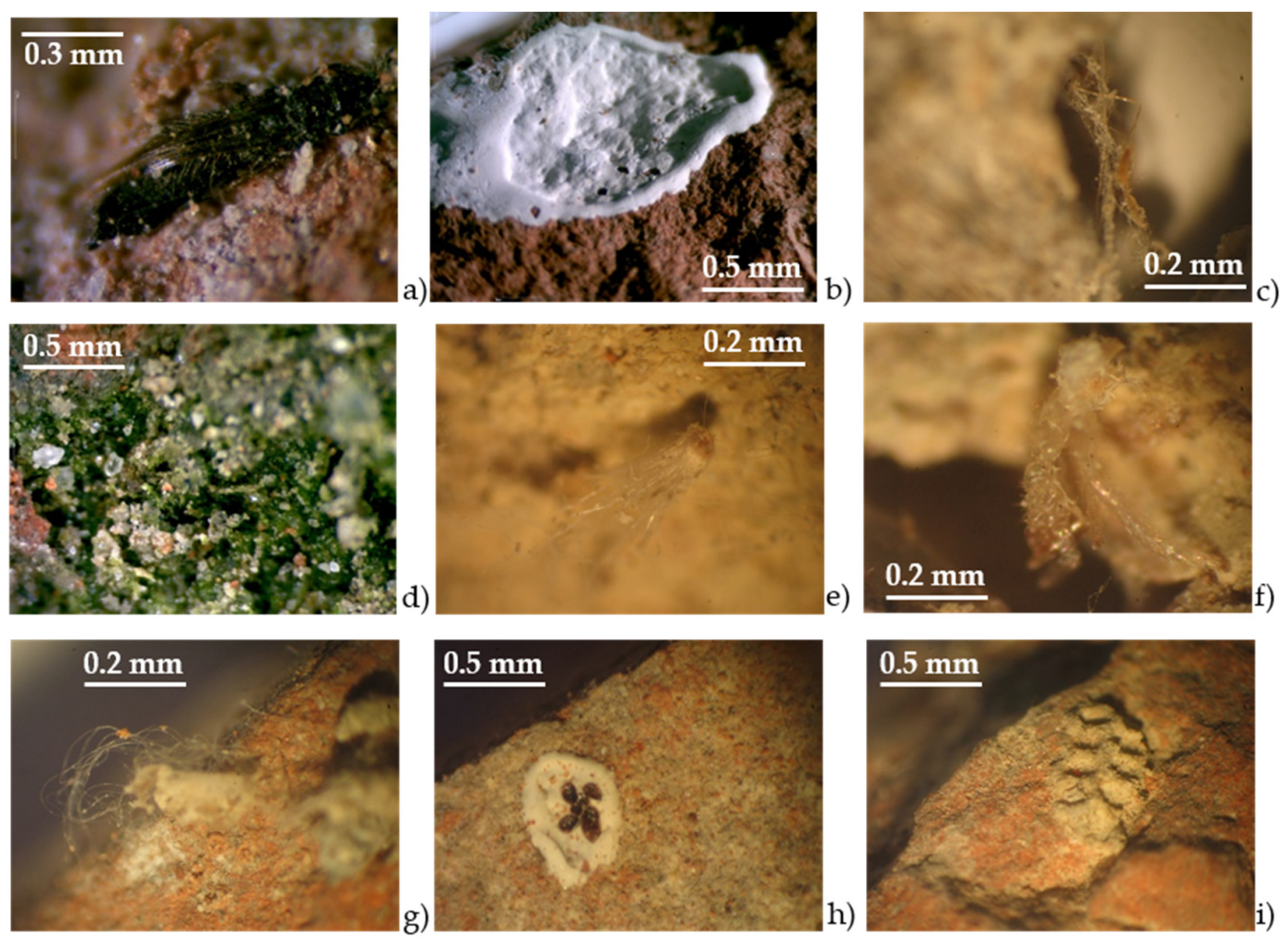

Figure 4. Photographs of the samples subject to degradation obtained thanks to a 5.0 Mp camera of the OPTIKA SZ 6745TR optical microscope: (a-c) biological degradation in the red brick of the sample P3; (d) example of algal biofilm in the brick of the sample P25bis; (e,f) biological degradation in the albasi brick of the sample P22; (g-i) biological degradation in the mortar of the sample P6. 
Figure 4a shows the image $(4.5 \times$ magnification) of the red brick P3, where small Thripidae (family of phytomitic insects of the order of Thysanoptera) was observed, with an elongated body generally black in color [37]. In the same sample, it was possible to observe the secretion of organic material by an arachnid female suitable for the creation of a nest in which she could then lay her eggs ( $0.67 \times$ magnification; Figure $4 b)$ [38], while Figure $4 \mathrm{c}$ shows an example of colonization of the faunal type (cobwebs).

Figure $4 \mathrm{~d}$ shows algal biofilm on red brick [39] of the P25bis sample (1.5 $\times$ magnification).

Cobwebs (Figure 4e, $4 \times$ magnification) and exuvia, abandoned remains of an exoskeleton of an arthropod after molting — in this case a pharyncnid (Figure 4f)—have been found in the albasi brick P22.

The cobwebs were also found in the mortar sample P6 (Figure 4g), while in Figure 4h,i two different types of colonization can be observed: Figure $4 \mathrm{~h}$ represents secretions of organic material emitted by an arachnid female suitable for the creation of a nest in which she could then lay her eggs (dark parts inside the whitish secretion), and in Figure 4i, it was possible to observe the secretion of organic matter through niches in which the eggs have been laid, now hatched or lost.

\subsection{XRF Analysis on the Soil Samples}

Seven samples of soils collected in the Valle del Mezzano, near to Valle Pega, were analyzed through XRF analyses. The results were shown in Table 2. Binary diagrams have been created to better understand the relationships between the major and minor elements, with the intention of providing a mineralogical characterization of the sampled soils (Figure 5). In each diagram, black rhombuses represent the seven samples investigated in this work; on the other hand, white squares represent samples collected in Valle Pega and analyzed in Baldini [24]. The two types of soils were compared in order to understand the relationships between the two adjacent areas, with a high probability of finding basins of the materials used in the construction of bricks and mortars.

Table 2. XRF data of the soil samples collected in Valle del Mezzano.

\begin{tabular}{|c|c|c|c|c|c|c|c|}
\hline & Sample 1 & Sample 2 & Sample 3 & Sample 4 & Sample 5 & Sample 6 & Sample 7 \\
\hline $\mathrm{SiO}_{2}$ & 45.67 & 70.94 & 60.92 & 36.39 & 49.69 & 58.48 & 47.51 \\
\hline $\mathrm{TiO}_{2}$ & 0.62 & 0.38 & 0.55 & 0.48 & 0.63 & 0.63 & 0.62 \\
\hline $\mathrm{Al}_{2} \mathrm{O}_{3}$ & 17.56 & 10.78 & 13.82 & 13.83 & 19.19 & 14.26 & 18.08 \\
\hline $\mathrm{Fe}_{2} \mathrm{O}_{3}$ & 8.17 & 2.59 & 4.57 & 7.17 & 7.26 & 4.60 & 7.54 \\
\hline $\mathrm{MnO}$ & 0.06 & 0.06 & 0.10 & 0.07 & 0.06 & 0.09 & 0.06 \\
\hline $\mathrm{MgO}$ & 3.56 & 3.71 & 4.24 & 3.44 & 3.12 & 4.33 & 3.49 \\
\hline $\mathrm{CaO}$ & 10.48 & 6.16 & 8.80 & 21.65 & 8.97 & 8.60 & 11.13 \\
\hline $\mathrm{Na}_{2} \mathrm{O}$ & 0.79 & 1.94 & 1.26 & 0.49 & 0.56 & 1.13 & 0.53 \\
\hline $\mathrm{K}_{2} \mathrm{O}$ & 2.88 & 2.11 & 2.55 & 2.24 & 3.16 & 2.56 & 3.09 \\
\hline $\mathrm{P}_{2} \mathrm{O}_{5}$ & 0.47 & 0.13 & 0.21 & 0.55 & 0.32 & 0.29 & 0.41 \\
\hline LOI & 9.74 & 1.20 & 2.98 & 13.67 & 7.05 & 5.03 & 7.53 \\
\hline Total & 100 & 100 & 100 & 100 & 100 & 100 & 100 \\
\hline $\mathrm{Ba}$ & 415.2 & 277.4 & 350.3 & 348.5 & 482.5 & 376.0 & 425.4 \\
\hline $\mathrm{Ce}$ & 67.8 & 41.8 & 54.3 & 75.0 & 63.8 & 53.6 & 78.8 \\
\hline Co & 18.5 & 13.1 & 17.6 & 15.1 & 19.6 & 20.3 & 23.2 \\
\hline $\mathrm{Cr}$ & 210.2 & 95.9 & 130.0 & 141.8 & 228.8 & 151.5 & 213.5 \\
\hline $\mathrm{La}$ & 28.7 & 20.7 & 26.0 & 27.0 & 22.2 & 23.1 & 25.3 \\
\hline $\mathrm{Nb}$ & 8.7 & 7.4 & 12.1 & 8.7 & 11.8 & 10.7 & 11.8 \\
\hline $\mathrm{Ni}$ & 132.9 & 80.4 & 102.9 & 111.6 & 149.8 & 113.1 & 149.9 \\
\hline $\mathrm{Pb}$ & 30.3 & 17.5 & 25.5 & 36.7 & 36.5 & 25.7 & 37.2 \\
\hline $\mathrm{Rb}$ & 134.2 & 82.4 & 116.2 & 100.9 & 163.7 & 105.3 & 158.4 \\
\hline $\mathrm{Sr}$ & 429.9 & 224.9 & 310.7 & 844.7 & 409.7 & 259.0 & 306.8 \\
\hline Th & 5.7 & 5.1 & 5.5 & 1.7 & 7.3 & 6.3 & 6.0 \\
\hline V & 133.3 & 54.8 & 90.3 & 111.4 & 152.7 & 100.6 & 141.6 \\
\hline $\mathrm{Y}$ & 16.0 & 20.6 & 25.5 & 15.5 & 22.9 & 22.2 & 21.7 \\
\hline $\mathrm{Zn}$ & 85.0 & 53.2 & 83.0 & 64.9 & 96.2 & 89.1 & 101.6 \\
\hline $\mathrm{Zr}$ & 73.0 & 104.7 & 141.0 & 62.4 & 82.2 & 136.0 & 88.5 \\
\hline $\mathrm{Cu}$ & 63.0 & 12.8 & 33.3 & 85.1 & 76.5 & 38.9 & 67.7 \\
\hline $\mathrm{Ga}$ & 21.4 & 6.3 & 10.2 & 15.9 & 22.5 & 13.7 & 20.5 \\
\hline $\mathrm{Nd}$ & 21.4 & 5.9 & 9.8 & 20.6 & 24.8 & 15.5 & 21.8 \\
\hline$S$ & $34,613.6$ & 2627.9 & 9076.3 & $35,649.8$ & $20,329.4$ & 3208.4 & $17,179.7$ \\
\hline $\mathrm{Sc}$ & 16.5 & 9.0 & 12.5 & 12.4 & 16.8 & 13.3 & 15.1 \\
\hline
\end{tabular}



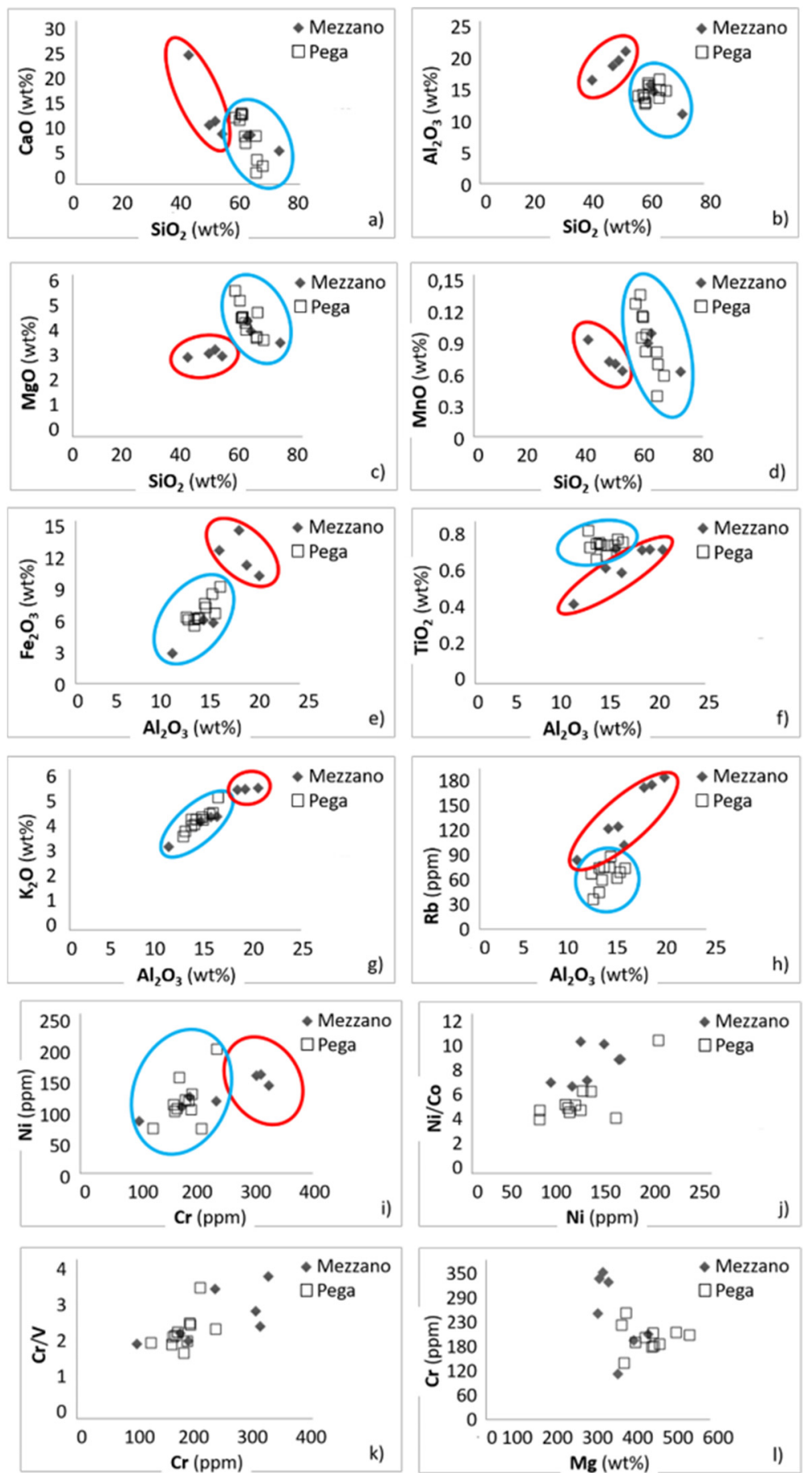

Figure 5. Binary diagrams between the major and minor elements obtained through XRF analyses and expressed in weight oxide (\%) for the major elements and in ppm for minor elements: (a) $\mathrm{SiO}_{2} / \mathrm{CaO}$; (b) $\mathrm{SiO}_{2} / \mathrm{Al}_{2} \mathrm{O}_{3}$; (c) $\mathrm{SiO}_{2} / \mathrm{MgO}$; (d) $\mathrm{SiO}_{2} / \mathrm{MnO}$; (e) $\mathrm{Al}_{2} \mathrm{O}_{3} / \mathrm{Fe}_{2} \mathrm{O}_{3}$; (f) $\mathrm{Al}_{2} \mathrm{O}_{3} / \mathrm{TiO}_{2}$; (g) $\mathrm{Al}_{2} \mathrm{O}_{3} / \mathrm{K}_{2} \mathrm{O}$; (h) $\mathrm{Al}_{2} \mathrm{O}_{3} / \mathrm{Rb}$; (i) $\mathrm{Cr} / \mathrm{Ni}$; (j) Ni-Ni/Co; (k) $\mathrm{Cr}-\mathrm{Cr} / \mathrm{V}$; (l) $\mathrm{MgO} / \mathrm{Cr}$. In each diagram, black rhombuses represent the seven samples analyzed in this work; white squares represent samples collected in Valle Pega [24].

The diagram in Figure 5a shows the relationships between $\mathrm{SiO}_{2} / \mathrm{CaO}$, in which there was a distinction in two main groups (expressed by red and blue circles in Figure 5a), accompanied by a negative correlation between the two oxides attributable to a compositional difference of the soil samples collected. The seven samples collected in Valle del 
Mezzano were comparable with the other samples collected in Valle Pega, except for only one sample. The Valle del Mezzano soil samples shown two different groups: one with a richer fraction in $\mathrm{CaO}$, an indicator of a low degree of alteration, while the second group, as for the soils of Valle Pega, shows a greater abundance of $\mathrm{SiO}_{2}$, probably due to alteration.

Additionally, in the diagram of Figure $5 b, \mathrm{SiO}_{2} / \mathrm{Al}_{2} \mathrm{O}_{3}$, we find the same negative trend. While the samples collected in Valle Pega were characterized by very similar concentrations of $\mathrm{SiO}_{2}$ and $\mathrm{Al}_{2} \mathrm{O}_{3}$, the samples collected in Valle del Mezzano could be divided into two main groups: a part with a higher aluminum oxide content, probably the most clayey part, and another part rich in silica, less clayey.

These latter considerations were also confirmed by the diagrams in Figure $5 \mathrm{c}, \mathrm{d}-$ $\mathrm{SiO}_{2} / \mathrm{MgO}$ and $\mathrm{SiO}_{2} / \mathrm{MnO}$, respectively - which have always shown the negative correlation and the division into two main groups of the samples collected in Valle del Mezzano, instead of the Valle Pega soils that were grouped together. In addition, the values relating to the relationship between $\mathrm{SiO}_{2} / \mathrm{MnO}$ show a positive correlation confirming the presence of oxides and hydroxides.

The positive correlation between $\mathrm{Al}_{2} \mathrm{O}_{3} / \mathrm{Fe}_{2} \mathrm{O}_{3}$ in the diagram of Figure $5 e$ was probably due to an accumulation of the clay component and the presence of hydroxides in the alluvial deposits present in the two sampling areas. Some soils of Valle del Mezzano have a positive correlation linked to the area distribution of the samples in the valley itself, opposite correlation for the other soils and for those of Valle Pega.

The diagram $\mathrm{Al}_{2} \mathrm{O}_{3} / \mathrm{TiO}_{2}$ (Figure $5 \mathrm{f}$ ) was similar to the diagram $\mathrm{SiO}_{2} / \mathrm{MgO}$ with the clear separation of the two different clay: soil samples of Valle Pega similar to each other in $\mathrm{Al}_{2} \mathrm{O}_{3}$ value (red circle in Figure $5 \mathrm{f}$ ) and with a higher oxide percentage content of $\mathrm{TiO}_{2}$ (blue circle in Figure 5f) in respect to the soil samples of Valle del Mezzano characterized by different contents of $\mathrm{Al}_{2} \mathrm{O}_{3}$ (between 10 to $20 \mathrm{wt} \%$ ).

Taking into consideration the diagrams of Figure $5 \mathrm{~g}, \mathrm{~h}-\mathrm{Al}_{2} \mathrm{O}_{3} / \mathrm{K}_{2} \mathrm{O}$ and $\mathrm{Al}_{2} \mathrm{O}_{3} / \mathrm{Rb}$, respectively - there was a positive correlation for both populations, i.e., for soil samples taken in the Valle del Mezzano and for those coming from Valle Pega. This trend confirms the relationship between aluminum oxide and potassium oxide, and this could represent the presence of fine sediments with a high content of illite, a mineral also of clay origin. The provenance from alluvial deposits was thus confirmed. The soils of Valle Pega slightly diversify in the $\mathrm{Al}_{2} \mathrm{O}_{3} / \mathrm{Rb}$ correlation which show an opposite trend to the soils of Valle del Mezzano.

By observing the values obtained through the relationship between $\mathrm{MgO}$ and $\mathrm{Cr}$ in the diagram of Figure $5 \mathrm{l}$ and the transition elements, such as $\mathrm{Cr}$ and Ni (diagram of Figure 5i), the graphs shown, in agreement also with the other data described above, different groups of soils containing clay minerals, alteration products of femic (in the blue circle in Figure 5i) and ultrafemic phases (in the red circle in Figure 5i).

Finally, the diagrams of Figure $5 \mathrm{j}, \mathrm{k}-\mathrm{Ni}-\mathrm{Ni} / \mathrm{Co}$ and $\mathrm{Cr}-\mathrm{Cr} / \mathrm{V}$, respectively-were examined. There was a division into two different groups, linked to the different concentrations of $\mathrm{Cr}$ and $\mathrm{Ni}$. In particular, the correlation between chromium and vanadium, in addition to the division into groups, had made it possible to associate the Mezzano samples with a more clayey component than those from Valle Pega, as also indicated by Rapti-Caputo et al. [40] and Abu Zeid et al. [41]. According to Amorosi et al. [42,43], the presence of geochemical indicators, such as $\mathrm{Ni}, \mathrm{Cr}, \mathrm{Co}$ and $\mathrm{V}$, reflects the association of a mineral phase within the same type of deposit, in this case an alluvial deposit.

\subsection{XRPD Data Analysis on Bricks, Mortars and Salt Crust}

As can be seen from the graphs in Figure 6, the XRPD analysis shown the following mineralogical phases, as regards the bricks: quartz $(\mathrm{Q})$, calcite $(\mathrm{Cc})$, dolomite (Do), feldspar (Feld), pyroxenes (Px), pectolite (Pct), pollastonite (Wo), melilite (Mel). Quartz (Q), calcite $(\mathrm{Cc})$ and pyroxenes $(\mathrm{Px})$ are, however, the phases found following the investigation of the mortars. As regards salt crusts, the presence of trona $(T)$, quartz $(\mathrm{Q})$, calcite $(\mathrm{Cc})$, feldspar (Feld) and pyroxenes (Px) has been found. After data comparison, it was noted that the 
phases present for each type of material were similar and common. For this reason, for each type of sample only one spectrum will be shown.
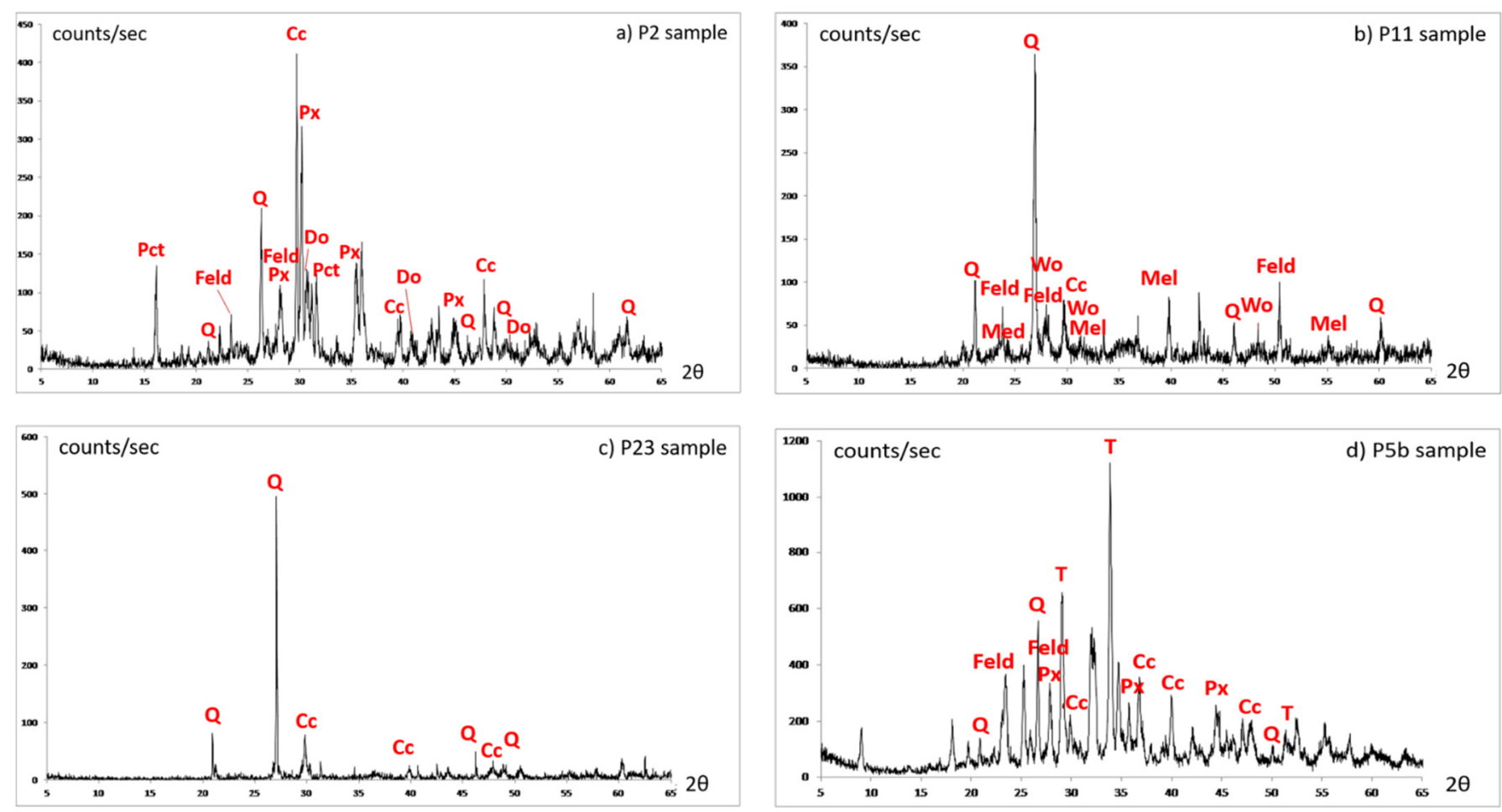

Figure 6. XRPD diffractogram of the analyzed samples: (a) example of albasi brick-Scheme 2; (b) example of red bricksample P11; (c) example of mortar—sample P23; (d) example of salt crust—P2. Pct, pectolite; Feld, feldspar; Px, pyroxenes; Wo, wollastonite; Mel, melilite; Q, quartz; Dol, dolomite; CC, calcite; T. trona.

Figure 6a shows the spectra representing albasi brick characterized by a greater abundance of crystalline phases since it was made up of less rich materials and a lower firing temperature [25]. The dissociation of carbonate releases abundant quantities of $\mathrm{CO}_{2}$, which inhibit the oxidation process of iron, thus giving the light color that these bricks present. In addition to the main phases originating from the clay with which the brick mix was made (quartz, calcite, dolomite, feldspar and pyroxenes), we also find pectolite, a thermos-metamorphic phase whose chemical formula was $\mathrm{NaCa}_{2} \mathrm{Si}_{3} \mathrm{O}_{8}(\mathrm{OH})$ [44]. The clay of origin with which the albasi bricks of the Santa Maria in Padovetere site were produced, in accordance with the phases analyzed, had a strong enrichment in sodium and calcium since it was an area subject to intense salinization. The Imperial Age, in fact, was characterized by high temperatures for an extended period. This favored a heating that led to a reduction in the aquifers and to an extensive phenomenon of salinization following to an intense evaporation of the water, which allowed the precipitation and the deposit of salts, such as, in our case, the trona. As a result, clays enriched in $\mathrm{Na}$ and Ca were obtained which, following interaction with the silicates and subject to firing for the production of the bricks, brought favorable conditions for the formation of the listed phases. These phases were observed only in the albasi bricks, since they were produced with lower firing temperatures [32] than red ones, as well as from less "selected" and more heterogeneous materials.

The red bricks showed similar phases to those of the albasi bricks, but with some differences. The spectra of Figure $6 \mathrm{~b}$ indicates quartz, calcite, feldspar and pyroxenes, indicators of the type of clay of origin with which the brick was produced, and only wollastonite and melilite, thermos-metamorphic phases generated after firing whose chemical formulas are respectively $\mathrm{CaSiO}_{3}$ and $(\mathrm{Ca}, \mathrm{Na})_{2}\left(\mathrm{Al}, \mathrm{Mg}, \mathrm{Fe}^{2+}\right)(\mathrm{Si}, \mathrm{Al})_{2} \mathrm{O}_{7}[44]$. These phases were also related to the presence of the mineral trona which conditioned their formation. 
There was no longer presence of pectolite (representing hydrated phase) probably due to the higher firing temperature.

The spectra obtained from the mortar samples were mainly characterized by the presence of quartz and calcite (Figure 6c). Phases related to local clays have been found, in accordance with the presence of river in the area [40].

Figure $6 \mathrm{~d}$ shows the XRPD spectra obtained from the salt crust analyses. The following mineralogical phases were observed: trona, quartz, calcite, feldspar and pyroxenes. Trona, a sodium hydrogen carbonate dehydrate, whose chemical formula was $\mathrm{Na}_{2}\left(\mathrm{CO}_{3}\right)\left(\mathrm{HCO}_{3}\right) \cdot 2\left(\mathrm{H}_{2} \mathrm{O}\right)$, was considered an environmental indicator of conditions of strong salinization, as it forms in arid conditions and in the presence of small water subject to intense evaporation [34]. The other phases (quartz, calcite, feldspar, pyroxenes), on the other hand, could be traced back to the brick from which the salt crust samples were collected.

\subsection{SEM-EDS Data Analysis on Bricks, Mortar and Salt Crust}

Due to the data obtained through the scanning electron microscope (SEM), it was possible to obtain information regarding the mineralogical and chemical nature of some samples: two albasi bricks (P20 and P21c), two red bricks (P16 and P27), the sample P14 (clay of the base) and a salt crust (P5b) were investigated.

Figure 7 shows the SEM-EDS data analyses (imaging and spectrum) of the five samples selected and Table 3 the results expressed in weight (\%).
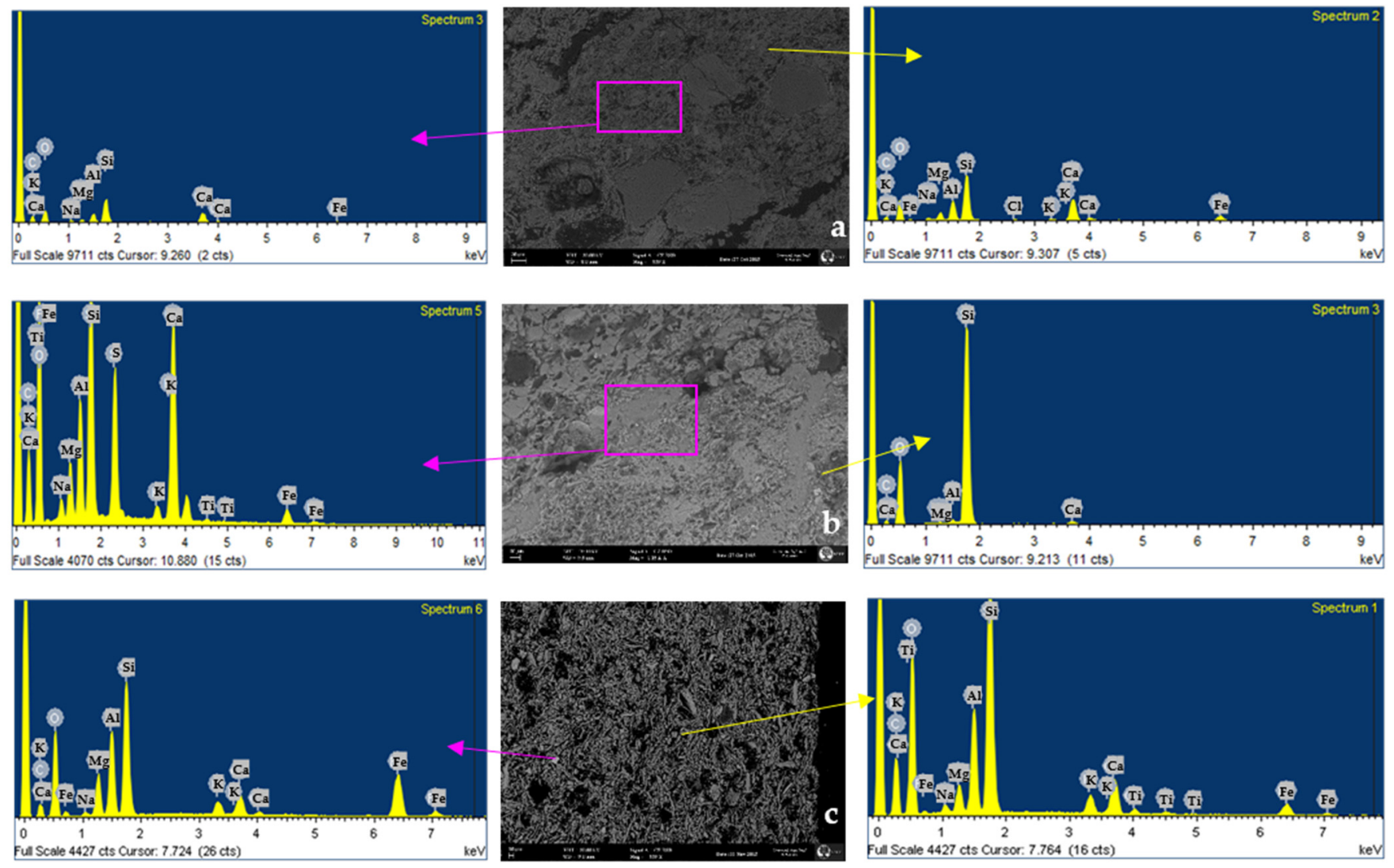

Figure 7. Cont. 

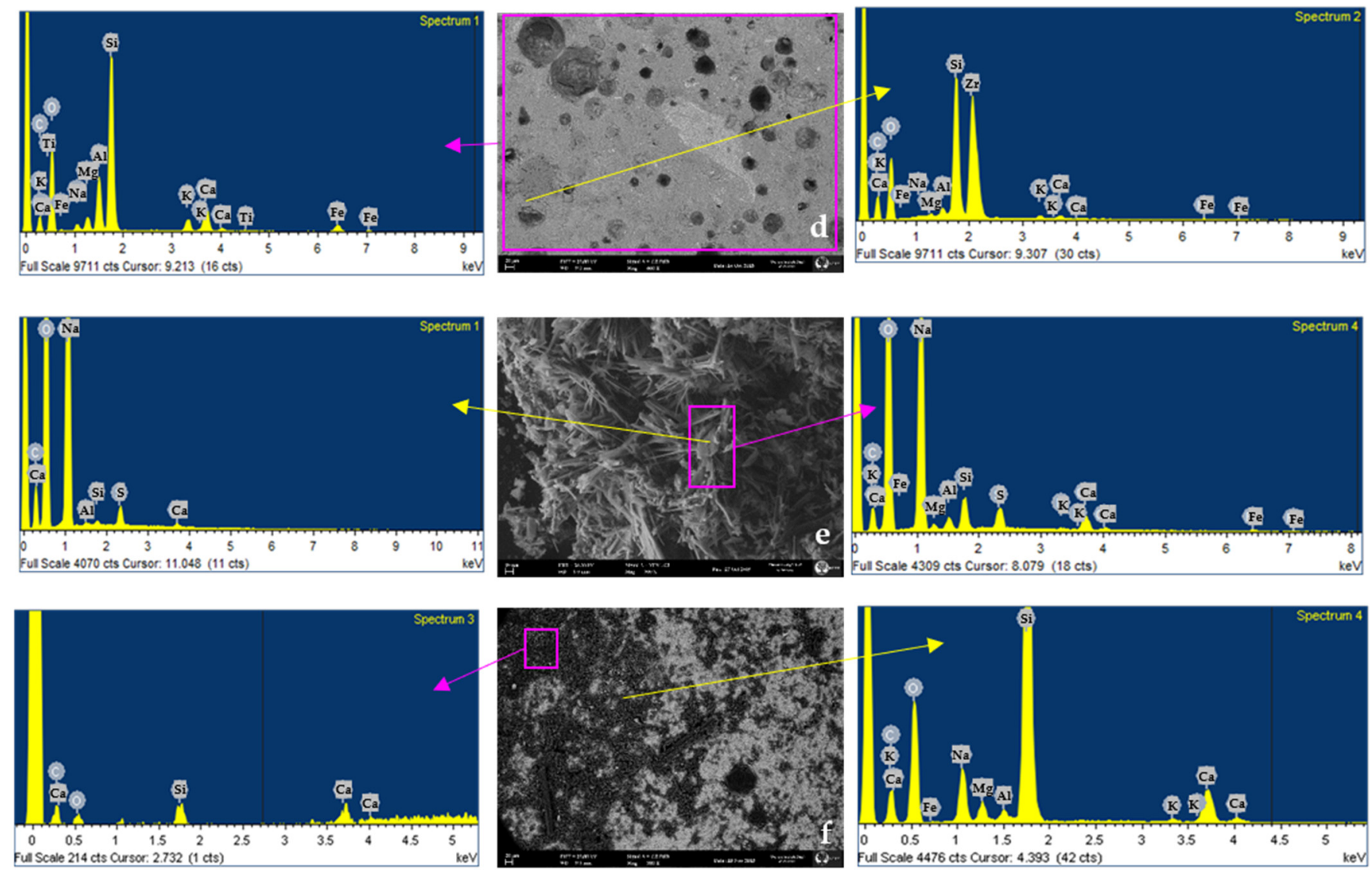

Figure 7. Photo imaging and spectrum obtained by SEM of different kind of samples, the pink square represents the area of analysis and the yellow circle the punctual analysis: (a) albasi brick of sample P20; (b) albasi brick of sample P21c; (c) red brick of sample P16; (d) red brick of sample P26; (e) salt crust of sample P5b; (f) base clay of sample P14.

Table 3. SEM-EDS data analyses of the five samples selected and expressed in weight (\%).

\begin{tabular}{|c|c|c|c|c|c|c|c|c|c|c|c|c|}
\hline & $\begin{array}{c}\text { Albasi } \\
\text { P20 Area }\end{array}$ & $\begin{array}{c}\text { Albasi } \\
\text { P20 } \\
\text { Punctual }\end{array}$ & $\begin{array}{c}\text { Albasi } \\
\text { P21c } \\
\text { Area }\end{array}$ & $\begin{array}{c}\text { Albasi } \\
\text { P21c } \\
\text { Punctual }\end{array}$ & $\begin{array}{c}\text { Red P16 } \\
\text { Area }\end{array}$ & $\begin{array}{l}\text { Red P16 } \\
\text { Punctual }\end{array}$ & $\begin{array}{c}\text { Red P27 } \\
\text { Area }\end{array}$ & $\begin{array}{l}\text { Red P27 } \\
\text { Punctual }\end{array}$ & $\begin{array}{c}\text { Saltcrust } \\
\text { P5b } \\
\text { Area }\end{array}$ & $\begin{array}{c}\text { Saltcrust } \\
\text { P5b } \\
\text { Punctual }\end{array}$ & $\begin{array}{c}\text { Clay P14 } \\
\text { Area }\end{array}$ & $\begin{array}{l}\text { Clay P14 } \\
\text { Punctual }\end{array}$ \\
\hline $\mathrm{C}$ & 34.45 & 11.35 & 23.58 & 10.46 & 29.25 & 17.65 & 19.56 & 31.34 & 13.22 & 12.06 & 41.71 & 28.29 \\
\hline $\mathrm{O}$ & 38.35 & 43.14 & 45.39 & 52.22 & 45.43 & 36.40 & 46.09 & 33.56 & 58.03 & 57.44 & 17.87 & 42.39 \\
\hline $\mathrm{Na}$ & 1.46 & 1.01 & 0.91 & 0.00 & 0.51 & 0.37 & 0.90 & 0.15 & 23.15 & 29.26 & 0.00 & 4.78 \\
\hline $\mathrm{Mg}$ & 1.21 & 2.26 & 1.79 & 0.19 & 1.41 & 4.32 & 1.46 & 0.14 & 0.34 & 0.00 & 0.00 & 1.23 \\
\hline $\mathrm{Al}$ & 3.55 & 4.67 & 3.12 & 0.41 & 4.48 & 7.70 & 4.94 & 0.51 & 0.64 & 0.10 & 0.00 & 0.46 \\
\hline $\mathrm{Si}$ & 10.85 & 11.13 & 8.35 & 35.56 & 12.35 & 13.14 & 17.86 & 8.82 & 1.74 & 0.15 & 6.38 & 19.00 \\
\hline $\mathrm{S}$ & 0.00 & 0.00 & 5.03 & 0.00 & 0.00 & 0.00 & 0.00 & 0.00 & 1.29 & 0.80 & 0.00 & 0.00 \\
\hline $\mathrm{Cl}$ & 0.40 & 0.12 & 0.00 & 0.00 & 0.00 & 0.00 & 0.00 & 0.00 & 0.00 & 0.00 & 0.00 & 0.00 \\
\hline $\mathrm{K}$ & 0.26 & 0.30 & 0.60 & 0.60 & 1.25 & 1.72 & 1.77 & 0.33 & 0.09 & 0.00 & 0.00 & 0.25 \\
\hline $\mathrm{Ca}$ & 7.25 & 5.69 & 9.36 & 0.91 & 2.66 & 2.93 & 4.14 & 0.42 & 1.23 & 0.19 & 6.94 & 3.34 \\
\hline $\mathrm{Ti}$ & 0.00 & 0.22 & 0.12 & 0.00 & 0.28 & 0.00 & 0.23 & 0.00 & 0.00 & 0.00 & 0.00 & 0.00 \\
\hline $\mathrm{Fe}$ & 2.22 & 2.43 & 1.75 & 0.25 & 2.37 & 15.77 & 3.05 & 0.32 & 0.28 & 0.00 & 27.10 & 0.25 \\
\hline $\mathrm{Zr}$ & 0.00 & 0.00 & 0.00 & 0.00 & 0.00 & 0.00 & 0.00 & 24.40 & 0.00 & 0.00 & 0.00 & 0.00 \\
\hline Total & 100 & 100 & 100 & 100 & 100 & 100 & 100 & 100 & 100 & 100 & 100 & 100 \\
\hline
\end{tabular}

The albasi brick samples show no significant differences between the two samples analyzed (P20 and P21c) and between area and point analyses. In all cases, Figure 7a,b shows a greater crystalline matrix than the red bricks (Figure 7c,d) probably due to the lower firing temperatures at which the albasi bricks were subject [32]. Both in the sample P20 and P21c, residual minerals were observed within the sample (Figure 7a,b), with, therefore, particle size heterogeneity. Both samples show different textures, probably due to the presence of more vitrified areas than others (probably due to the mixture of different types of clay having different properties, such as plasticity). Additionally, in regard to porosity, a difference can be seen compared to red bricks: in this case, in fact, the lack of 
porosity was not so accentuated within the albasi bricks. Figure $7 \mathrm{~b}$ shows a sample of albasi brick characterized by a "mixed" composition, produced by different types of clay that, in addition to giving a mottled coloring, generate a heterogeneous composition of the chemical components. The investigated area was located in a transition area between one type of clay and another: above the light albasi part, below the more ferromagnetic part coming from another type of clay, as shown in Table 3 in which it was possible to observe the ferromagnetic presence in the albasi sample with value between 0.25 to 2.43 . All the albasi samples were characterized by high value of silica (between 8.35 to 10.85 in the area analyzed) and calcium (between 7.25 to 9.36 in the area analyzed). It is important to note the punctual analyses of the albasi sample P21c with a very-high value of silica (35.56) and lower value of calcium (0.91).

As regards the two samples of red brick (P16 and P27), they presented evident differences between the two samples. The sample P16 did not show a particular evidence of porosity (Figure 7c) which, however, happened in the sample P27 in which roundish vacuoles were clearly recognizable (Figure $7 \mathrm{~d}$ ). The presence of vacuoles could indicate a sintering process, a particular heat treatment that transforms a material into an indivisible one; there was, therefore, a sufficient fusion to get to free the volatile phases, which, for example, was not the case in the albasi bricks. Furthermore, we noted a tendency towards compositional and textural homogeneity; the original clay from which the brick was then produced was well screened. Through the backscattering mode, the analysis carried out in a point of the matrix allows the identification of the distribution of the elements, which mainly showed $\mathrm{Si}, \mathrm{Al}, \mathrm{Mg}, \mathrm{K}$ and $\mathrm{Fe}$, that probably conferred that intense red color to the brick. Furthermore, there was the presence of $\mathrm{Ca}$ (range value between 2.66 and 4.14 in the area analyzed), $\mathrm{O}$ and $\mathrm{C}$, possibly attributable to the presence of trona. They were therefore clay-type minerals with a clear abundance of iron, which probably gave the brick an intense red-brownish appearance. Table 3 shows very close iron values in the areas analyzed between 2.37 and 3.05 and a very different value in the punctual analyses between 15.77 (sample P16) and 0.32 (sample P27). Sample P27 was also characterized by high value of $\mathrm{Zr}(24.40 \mathrm{wt} \%)$ that was observed only in this sample. The analyses allowed to identify the distribution of the iron-magnetic phases of the oxides, the presence of which was widespread in the matrix characterized by the presence of large quantities of kaolin probably came from rocks schistose and mainly by mica schists [45].

Sample P5b represented an example of a saline crust. This sample looked like a whitish crystalline powder under the optical microscope, while instead they show their needle-like and fibrous shape thanks to the SEM instrumentation (Figure 7e). The sample was mainly composed of $\mathrm{Na}_{2} \mathrm{CO}_{3}$, specifically a sodium carbonate dehydrates called trona (sodium was present with very-high values between 23.15 and 29.26, as shown in Table 3). In the spectrum of Figure 7e, it was possible to observe the presence of elements constituting the trona and other residues referring to the brick from which the salt crust was sampled, such as $\mathrm{Ca}, \mathrm{Al}, \mathrm{Si}, \mathrm{Fe}$ and $\mathrm{Mg}$.

The P14 clay sample was collected immediately below the foundations, in order to obtain some additional information on the compositional distribution of the clays present in the sampling site area. The sample was collected about $1.60 \mathrm{~m}$ below the countryside level, thanks to a survey excavation already opened by the Superintendence of Cultural Heritage of the city of Bologna. It presents textural and compositional heterogeneity. Inside, residual minerals and probably organic fragments were observed. Through areal and punctual analyses (Figure 7f), chosen in order to obtain semi-quantitative information on the distribution of the elements present in the matrix, $\mathrm{Si}, \mathrm{Ca}, \mathrm{Mg}, \mathrm{Al}$ and $\mathrm{K}$ were detected; moreover, $\mathrm{Na}, \mathrm{O}$ and $\mathrm{C}$, probably attributable to the presence of trona. The SEM-EDS analyses obtained were in agreement with Rapti-Caputo et al. [40], as well as with the mineralogical phases obtained with the XRD analysis. Following these analyses, considering the history, uses and possibilities of the time, it was possible to hypotheses a production made with locally materials. 


\section{Discussion}

As already understood during the sampling campaigns and subsequent analyses, we could declare that almost all of the red bricks collected in the Santa Maria in Padovetere site were posthumously laid for the construction and the period of the site. These samples were textural and compositionally different from those attributed to be "original" which were produced thanks to production techniques that cannot be combined with those of the time. In fact, it can be noted that the red bricks presented mineralogical phases (i.e., wollastonite and melilite) whose formation take place at high temperatures [46], difficult to implement in the Imperial Age. From historical documents, we know, in fact, that this site was redeveloped between the 1950s and 1970s, not following precise and appropriate rules. For this reason, in addition to the use of reuse materials, we could find the laying of bricks clearly recently produced.

Table 4 proposes an estimate of the firing temperatures to which the brick samples were subjected, according to the mineralogical phases found, and also in accordance with Duminuco et al. [47]. Considering the results obtained by XRPD bulk analyses (Table 4) and in accordance with Duminuco et al., Bianchini et al. [47,48], it could be proposed that the presence of carbonates and/or clinopiroxens suggests that defined equilibrium conditions of the mixtures were not attained. This could be assigned to the inhomogeneity of the original starting materials that caused limited mobility of the chemical species during the firing processes $[47,48]$.

Samples P2, P20 and P22 (albasi bricks) show lower firing temperatures, between 750 and $800{ }^{\circ} \mathrm{C}$ [32], confirming the differences between the albasi and the red brick. In fact, between 850 and $900{ }^{\circ} \mathrm{C}$, however, the samples of red bricks P3 and P25 were observed, in which there was the disappearance of dolomite and pectolite, but the formation of wollastonite. By rising in temperature, from 900 to $1000^{\circ} \mathrm{C}$, samples P9, P11, P12 and P26 also shows the presence of melilite, demonstrating high temperature.

As suggested by Duminuco et al., Bianchini et al. [47,48], XRPD bulk analyses cannot be considered completely reliable for the estimation of firing temperatures; this is clear considering some samples characterized by "ambiguous parageneses" containing carbonate minerals (an indicator of low firing temperature, i.e., $<850^{\circ} \mathrm{C}$ ) and clinopyroxene and /or plagioclase (usually considered high-temperature products, i.e., $>950^{\circ} \mathrm{C}$ ).

Finally, the P21d sampling always shows the presence of melilite, but the disappearance of wollastonite, thus being able to affirm that this red brick was produced at a temperature higher than $1000^{\circ} \mathrm{C}$.

Feldspars, pyroxenes and quartz were always present.

The high firing temperature of the red bricks probably caused the high porosity of the materials, as previously observed by microscopic observations and confirmed by literature data [49].

Table 4. Mineralogical phase in the samples analyzed and estimate of the firing temperatures of the bricks. The abbreviations are as follows as requested by Whitney [50]: Pct, pectolite; Fsp, feldspar; Px, pyroxene; Wo, wollastonite; Mll, melilite; Qz, quartz; Dol, dolomite; CC, calcite.

\begin{tabular}{|c|c|c|c|c|c|c|c|c|c|}
\hline \multirow[t]{3}{*}{ Estimated $\mathrm{T}^{\circ}$} & \multirow[t]{3}{*}{ Sample } & \multicolumn{6}{|c|}{ Primary Phases Present in the Bricks } & \multirow{2}{*}{\multicolumn{2}{|c|}{$\begin{array}{l}\text { Secondary Phases } \\
\text { Carbonates }\end{array}$}} \\
\hline & & \multicolumn{5}{|c|}{ Silicates-Rising $\mathbf{T}^{\circ}$} & \multirow[b]{2}{*}{ Qz } & & \\
\hline & & Pct & Fsp & Px & Wo & Mll & & Dol & $\mathrm{CC}$ \\
\hline \multirow{3}{*}{$750-800^{\circ}$} & P2 & $x$ & $\mathrm{x}$ & $x$ & & & $\mathrm{X}$ & $\mathrm{X}$ & $\mathrm{X}$ \\
\hline & P20 & $x$ & $x$ & $x$ & & & $\mathrm{X}$ & $x$ & $x$ \\
\hline & $\mathrm{P} 22$ & $x$ & $X$ & $x$ & & & $x$ & $x$ & $x$ \\
\hline \multirow{3}{*}{$850-900^{\circ}$} & P3 & & $x$ & $x$ & $X$ & & $X$ & & $X$ \\
\hline & P25 & & $X$ & & $x$ & & $X$ & & $X$ \\
\hline & P9 & & $x$ & $x$ & $x$ & $x$ & $X$ & & $X$ \\
\hline \multirow{3}{*}{$900-1000^{\circ}$} & P11 & & $x$ & & $x$ & $x$ & $\mathrm{X}$ & & $x$ \\
\hline & P12 & & $x$ & $x$ & $X$ & $x$ & $X$ & & $x$ \\
\hline & P26 & & $X$ & $X$ & $x$ & $X$ & $X$ & & $X$ \\
\hline$>1000^{\circ}$ & P21d & & $X$ & $x$ & & $X$ & $X$ & & \\
\hline
\end{tabular}




\section{Conclusions}

This work aims to provide preliminary elements regarding the different composition of bricks and mortars used in the construction of the archeological site of Santa Maria in Padovetere (Comacchio, Ferrara).

Thanks to the analyses carried out on different types of samples, it was possible to hypothesize the different construction phases and the different materials used and to identify the firing temperatures at which the bricks were built.

Furthermore, following the sampling of soils collected in the Valle del Mezzano area, it was possible to investigate the origin of the materials used in the construction of the parish.

The sampled bricks and the saline fluorescence founded and collected on the site were investigated by XRPD and SEM-EDS, as well as under the optical microscope. The data obtained shows the predominant presence of a sodium carbonate dehydrate, called trona, whose existence on the territory was mainly linked to an area that in the Imperial Age (period in which the parish developed) was characterized by a strong salinization. The presence of trona in sediments and rocks, which distinguishes the substrate on which the parish church of Santa Maria in Padovetere was located, had affected the degradation of the bricks. In addition, it had probably influenced the formation of mineralogical phases following the firing process of the bricks derived from the interaction between trona and the origin clays used for the matrix.

Through XRPD data it was possible to provide an estimate on the firing temperatures of the samples: the albasi bricks show lower firing temperatures and phases such as quartz, calcite, dolomite, feldspar, pyroxenes, pectolite and they represented the historical bricks; as regards, however, the red bricks, i.e., those of replacement and redevelopment of the archeological site between the 1950s and 1970s, are differentiated from the others, as well as for the coloring and texture, also for the presence of minerals such as wollastonite and melilite. From these thermos-metamorphic phases, derived from firing at higher temperatures and in the presence of trona in the clay, it can be assumed that these bricks came from better screened clays and more "modern" production materials. Thanks to these data, it was possible to better understand the reconstruction of the building phases of the Santa Maria parish.

The sampling of soils carried out in the Valle del Mezzano (valley adjacent to the Valle Pega where the parish was located) made it possible to understand the origin of the materials used in the construction of the parish. Through XRF analyses, two main groups were found, related to a different composition of the soil samples collected and, therefore, to two different types of alluvial contributions: a more clayey fraction than the other.

This research provides a base for future investigations and research activities, such as obtaining information on the possible use of the lagoons to produce the mineral trona, providing a clear and detailed outline of the raw materials used in the construction of the parish church of Santa Maria in Padovetere and, finally, contributing to the identification of the areas used for the collection of raw materials used in the production of bricks in the Comacchio area.

Author Contributions: Conceptualization, M.C. and M.M.; Methodology, E.M. and C.T.; Validation, E.M., C.T., M.C. and M.M.; Formal Analysis, E.M. and C.T.; Investigation, E.M., M.C. and M.M.; Data Curation, E.M., C.T., M.C. and M.M.; Writing-Original Draft Preparation, E.M., C.T., M.C. and M.M.; Writing-Review and Editing, E.M. and C.T.; Visualization, E.M. and C.T.; Supervision, M.C. and M.M.; Project Administration, M.M. All authors have read and agreed to the published version of the manuscript.

Funding: This research received no external funding.

Acknowledgments: The authors wish to thank Dott.ssa Sara Squintani for helping us in our research and the direction of the Superintendence for making the samples available.

Conflicts of Interest: The authors declare no conflict of interest. 


\section{References}

1. Wheeler, D.L. Land Reclamation in the Po River Delta of Italy. Land Econ. 1965, 41, 376-382. [CrossRef]

2. Cencini, C. Physical Processes and Human Activities in the Evolution of the Po Delta, Italy. J. Coast. Res. 1998, 14, 774-793.

3. Gelichi, S. Gli scavi archeologici intorno alla Cattedrale di Comacchio. The Archaeological Excavations nearby the Comacchio Cathedral. In L'isola del Vescovo; All'insegna del Giglio: Borgo San Lorenzo, Italy, 2009; pp. 1-88.

4. McCormick, M. Comparing and connecting: Comacchio and the early medieval trading towns. In From One Sea to Another: Trading Places in the European and Mediterranean Early Middle Ages, Proceedings of the International Conference, Comacchio, Italy, 27-29 March 2009; Gelichi, S., Hodges, R., Eds.; Turnhout Brepols Publishers: Turnhout, Belgium, 2013; pp. 477-502. [CrossRef]

5. Mini, F.M.; Santi, P.; Renzulli, A.; Riccardi, M.P.; Antonelli, F.; Alberti, A. Representative archaeological finds of pietra ollare from Comacchio (Italy): Identifying provenance and high-T mineral breakdown reactions hindering lithotype classification. Archaeol. Anthr. Sci. 2016, 8, 135-148. [CrossRef]

6. Gelichi, S. Chapter 7: Comacchio: A Liminal Community in a Nodal Point during the Early Middle Ages. In Venice and Its Neighbors from the 8th to 11th Century: Through Renovation and Continuity; The Medieval Mediterranean; Brill: Leiden, The Netherlands, 2017; Volume 7, pp. 142-167. [CrossRef]

7. Alfieri, N. La pianura ferrarese nell'antichità. In Il Po, la Cattedrale, la Corte dalle Origini al 1598; Renzi, R., Ed.; Edizioni Alfa Bologna: Bologna, Italy, 1969; Volume 1.

8. Alfieri, N. La ricerca e la scoperta di Spina. In Spina: Storia di Una Città tra Greci ed Etruschi, Proceedings of the Exhibition, Ferrara-Castello Estense, Italy, 26 September 1993-15 May 1994; Berti, F., Guzzo, G., Eds.; Ferrara Arte: Ferrara, Italy, 1993 ; pp. 3-19.

9. Hostetter, E. Banqueting Bronzes at Spina: The Archaeological Context. J. Etruscan Found. 1998, 5, 1-26. [CrossRef]

10. Rucco, A.A. From documents to the ground. The early medieval landscape of Comacchio. Reti Medievali Rivista 2015, 16, 197-229. [CrossRef]

11. Beltrame, C.; Costa, E. A 5th-Century-AD Sewn-Plank River Barge at St Maria in Padovetere (Comacchio-FE), Italy: An interim report. Int. J. Naut. Archaeol. 2016, 45, 253-266. [CrossRef]

12. Beltrame, C.; Mozzi, P.; Forti, A.; Maritan, M.; Rucco, A.A.; Vavasori, A.; Miola, A. The Fifth-Century AD Riverine Barge of Santa Maria in Padovetere (Ferrara, Italy): A Multidisciplinary Approach to its Environment and Shipbuilding Techniques. Environ. Archaeol. 2019. [CrossRef]

13. Corti, C. Santa Maria in Padovetere: La chiesa, la necropoli e l'insediamento circostante. In Genti del Delta da Spina a Comacchio; Corbo Editore: Ferrara, Italy, 2007; pp. 531-535.

14. Beltrame, C.; Forti, A.; Maritan, M.; Miola, A.; Mozzi, P.; Rucco, A.A.; Vavasori, A. Multidisciplinary research in naval archaeology: The shipwreck of Santa Maria in Padovetere (Ferrara, N Italy). In Humans and Environmental Sustainability: Lessons from the Past Ecosystems of Europe and Northern Africa, Proceedings of the 14th Conference on Environmental Archaeology, Modena, Italy, 26-28 February 2018; CEA: Milan, Italy, 2018; pp. 81-82.

15. Peters, T.J.; Iberg, R. Mineralogical changes during firing of Ca-rich brick clays. Am. Ceram. Soc. Bull. 1978, 57, 503-506.

16. Maggetti, M. Majolika aus Mexiko: Ein archa biometrisches Fallbeispiel. Fortschr Miner 1986, 64, 87-103.

17. Heimann, R.B. Assessing the technology of ancient pottery: The use of ceramic phase diagrams. Archeomaterials 1989, 3, 123-148.

18. Riccardi, M.P.; Messiga, B.; Duminuco, P. An approach to the dynamics of clay firing. Appl. Clay Sci. 1999, 15, 393-409. [CrossRef]

19. Coletti, C.; Cultrone, G.; Maritan, L.; Mazzoli, C. How to face the new industrial challenge of compatible, sustainable brick production: Study of various types of commercially available bricks. Appl. Clay Sci. 2016, 124, 219-226. [CrossRef]

20. Secco, M.; Previato, C.; Addis, A.; Zago, G.; Kamsteeg, A.; Dilaria, S.; Canovaro, C.; Artioli, G.; Bonetto, J. Mineralogical clustering of the structural mortars from the Sarno Baths, Pompeii: A tool to interpret construction techniques and relative chronologies. J. Cult. Herit. 2019, 40, 265-273. [CrossRef]

21. Adorni, E.; Coïsson, E.; Ferretti, D. In situ characterization of archaeological adobe bricks. Constr. Build. Mater. 2013, 40, 1-9. [CrossRef]

22. Miriello, D.; Barca, D.; Bloise, A.; Ciarallo, A.; Crisci, G.M.; De Rose, T.; Gattuso, C.; Gazineo, F.; La Russa, M.F. Characterisation of archaeological mortars from Pompeii (Campania, Italy) and identification of construction phases by compositional data analysis. J. Archaeol. Sci. 2010, 37, 2207-2223. [CrossRef]

23. Lopez-Arce, P.; Garcia-Guinea, J. Weathering traces in ancient bricks from historic buildings. Build Environ 2005, 40, 929-941. [CrossRef]

24. Baldini, C. Analisi Geochimiche del Sito Archeologico di Santa Maria in Padovetere. Ph.D. Thesis, Ferrara University, Ferrara, Italy, 2013-2014.

25. Bruni, S.; Maino, G.; Marrocchino, E.; Vaccaro, C.; Volpe, L. A study of the Civic Tower in Ravenna as an example of medieval towers' preservation problems. Eur. Phys. J. Plus 2013, 128, 33. [CrossRef]

26. Marrocchino, E.; Telloli, C.; Novara, P.; Meletti, V.; Vaccaro, C. Petro-archaeometric characterization of historical mortars in the city of Ravenna (Italy). In Proceedings of the 2020 IMEKO TC-4 International Conference on Metrology for Archaeology and Cultural Heritage, Trento, Italy, 22-24 October 2020.

27. Marrocchino, E.; Telloli, C.; Pedrini, M.; Vaccaro, C. Natural stones used in the Orsi-Marconi palace façade (Bologna): A petro-mineralogical characterization. Heritage 2020, 3, 1109-1123. [CrossRef]

28. Telloli, C.; Chicca, M.; Pepi, S.; Vaccaro, C. Saharan dust particles in snow samples of Alps and Apennines during an exceptional event of transboundary air pollution. Environ. Monit. Assess. 2018, 109, 1-15. [CrossRef] 
29. Marrocchino, E.; Telloli, C.; Vaccaro, C. Geochemical and mineralogical characterization of construction materials from historical buildings of Ferrara (Italy). Geosciences 2021, 11, 31. [CrossRef]

30. Marrocchino, E.; Telloli, C.; Vaccaro, C. Microscopic and chemical characterization of metal slags found at the Porta Paola excavation in Ferrara. In Proceedings of the 2020 IMEKO TC-4 International Conference on Metrology for Archaeology and Cultural Heritage, Trento, Italy, 22-24 October 2020.

31. Lachance, G.R.; Traill, J.R. Practical solution to the matrix problem in X-ray analysis. Can. Spectrosc. 1966, 11, 43-48.

32. Antonelli, F.; Cancelliere, S.; Lazzarini, L. Minero-petrographic characterisation of historic bricks in the Arsenale, Venice. J. Cult. Herit. 2002, 3, 59-64. [CrossRef]

33. Oliveira, M.L.S.; Flore, E.M.M.; Dotto, G.L.; Neckel, A.; Silva, L.F.O. Nanomineralogy of mortars and ceramics from the Forum of Caesar and Nerva (Rome, Italy): The protagonist of black crusts produced on historic buildings. J Clean Prod 2021, 278, 123982. [CrossRef]

34. Cultrone, G.; De la Torre, M.J.; Sebastian, E.M.; Cazalla, O.; Rodriguez-Navarro, C. Behavior of Brick Samples in Aggressive Environments. Water Air Soil Pollut. 2000, 119, 191-207. [CrossRef]

35. Marrocchino, E.; Rapti-Caputo, D.; Vaccaro, C. Chemical-mineralogical characterisation as useful tool in the assessment of the decay of the Mesola Castle (Ferrara, Italy). Constr. Build. Mater. 2010, 24, 2672-2683. [CrossRef]

36. Přikryl, R.; Svobodová, J.; Zák, K.; Hradil, D. Anthropogenic origin of salt crusts on sandstone sculptures of Prague's Charles Bridge (Czech Republic): Evidence of mineralogy and stable isotope geochemistry. Eur. J. Miner. 2004, 16, 609-618. [CrossRef]

37. Camelo-García, V.M.M.; Lima, E.F.B.; Rezende, J.A.M. Rearing Frankliniella zucchini Nakahara \& Monteiro (Thysanoptera: Thripidae) on zucchini (Cucurbita pepo L. 'Caserta') fruits. Rev. Bras. Entomol. 2019, 63, 115-118.

38. Humphreys, W.F. The accoutrements of spiders' eggs (Araneae) with an exploration of their functional importance. Zool. J. Linn. Soc. 1987, 89, 171-201. [CrossRef]

39. Quagliarini, E.; Gianangeli, A.; D’Orazio, M.; Gregorini, B.; Osimani, A.; Aquilanti, L.; Clementi, F. Effect of temperature and relative humidity on algae biofouling on different fired brick surfaces. Constr. Build. Mater. 2019, 19928, 396-405. [CrossRef]

40. Rapti-Caputo, D.; Pavanelli, D.; Tassinari, R.M.; Vaccaro, C. Caratterizzazione geochimica dei sedimenti e delle acque del Fiume Reno. In Atti II Giornata di Studio sul Monitoraggio Idrotorbidimetrico dei Corsi d'Acqua per la Stima dei Processi Erosivi E il Bilancio dei Solidi Sospesi; Donatella Pavanelli-Università di Bologna: Bologna, Italy, 2004.

41. Abu Zeid, N.; Marrocchino, E.; Vaccaro, C.; Nieto, D.; Martinucci, M. Geological and Geophysical Investigation of "Site Effects" Due to Liquefaction in Mirabello Following the May 20th, 2012 Emilia Earthquake; EAI: Milan, Italy, 2012; Parte II; pp. 4-5.

42. Amorosi, A.; Centineo, M.C.; Dinelli, E.; Lucchini, F.; Tateo, F. Geochemical and mineralogical variations as indicators of provenance changes in Late Quaternary deposits of SE Po Plain. Sediment. Geol. 2002, 151, 273-292. [CrossRef]

43. Amorosi, A.; Guermandi, M.; Marchi, N.; Sammartino, I. Fingerprinting sedimentary and soil units by their natural metal contents: A new approach to assess metal contamination. Sci. Total Environ. 2014, 500, 361-372. [CrossRef]

44. Salman, S.M.; Salama, S.N.; Abo-Mosallam, H.A. The crystallization behaviour and bioactivity of wollastoniteglass-ceramic based on $\mathrm{Na}_{2} \mathrm{O}-\mathrm{K}_{2} \mathrm{O}-\mathrm{CaO}-\mathrm{SiO}_{2}-\mathrm{F}$ glass system. J. Asian Ceram. Soc. 2015, 3, 255-261. [CrossRef]

45. Kadï, S.; Akbulut, A. Mineralogy, geochemistry and genesis of the Taşoluk kaolinite deposits in pre-Early Cambrian metamorphites and Neogene volcanites of Afyonkarahisar, Turkey. Clay Min. 2009, 44, 89-112. [CrossRef]

46. Cultrone, G.; Carrillo Rosua, F.J. Growth of metastable phases during brick firing: Mineralogical and microtextural changes induced by the composition of the raw material and the presence of additives. Appl. Clay Sci. 2020, 185, 105419. [CrossRef]

47. Duminuco, P.; Messiga, B.; Riccardi, M.P. Firing process of natural clays. Some microtextures and related phase compositions. Thermochim. Acta 1998, 321, 185-190. [CrossRef]

48. Bianchini, G.; Marrocchino, E.; Moretti, A.; Vaccaro, C. Chemical-mineralogical characterization of historical bricks from Ferrara: An integrated bulk and micro-analitycal approach. In Geomaterials in Cultural Heritage; Special Publication; Maggetti, M., Messiga, B., Eds.; Geological Society: London, UK, 2006; Volume 257, pp. 127-140. [CrossRef]

49. Cultrone, G.; Sebastian, E.; Elert, K.; de la Torre, M.J.; Cazalla, O.; Rodriguez-Navarro, C. Influence of mineralogy and firing temperature on the porosity of bricks. J. Eur. Ceram. Soc. 2004, 24, 547-564. [CrossRef]

50. Whitney, D.L. Abbreviations for Names of Rock-Forming Minerals. Am. Miner. 2010, 95, 185-187. [CrossRef] 